\title{
NDA SAFEGUARDS TECHNIQUES FOR LMFBR ASSEMBLIES
}

by

\author{
P. J. Persiani and $M$. L. Gundy
}

ARGONNE NATIONAL LABORATOAY, ARGONNE, ILLINOIS

Prepared for the U. S. DEPARTMENT OF ENERGY

under Contract W-31-109-Eng-38 
The facilities of Argonne National Laboratory are owned by the United States Government. Under the terms of a contract (W-31-109-Eng-38) among the U.S. Department of Energy, Argonne Universities Association and The University of Chicago, the University employs the staff and operates the Laboratory in accordance with policies and programs formulated, approved and reviewed by the Association.

\section{MEMBERS OF ARGONNE UNIVERSITIES ASSOCIATION}

The University of Arizona Carnegie-Mellon University Case Western Reserve University The University of Chicago University of Cincinnati Illinois Institute of Technology University of Illinois Indiana University The University of Iowa Iowa State University
The University of Kansas Kansas State University Loyola University of Chicago Marquette University The University of Michigan Michigan State University University of Minnesota University of Missouri Northwestern University University of Notre Dame
The Ohio State University Ohio University The Pennsylvania State University Purdue University Saint Louis University Southern Illinois University The University of Texas at Austin Washington University Wayne State University The University of Wisconsin-Madison

\section{NOTICE}

This report was prepared as an account of work sponsored by an agency of the United States Government. Neither the United States Government nor any agency thereof, nor any of their employees, makes any warranty, express or implied, or assumes any legal liability or responsibility for the accuracy, completeness, or usefuiness of any information, apparatus, product, or process disclosed, or represents that its use would not infringe privately owned rights. Reference herein to any specific commercial product, process, or service by trade name, trademark, manufacturer, or otherwise, does not necessarily constitute or imply its endorsement, recommendation, or favoring by the United States Government or any agency thereof. The views and opinions of authors expressed herein do not necessarily state or reflect those of the United States Government or any agency thereof.

Printed in the United States of America Available from

National Technical Information Service

U. S. Department of Commerce

5285 Port Royal Road

Springfield, VA 22161

NTIS price codes

Printed copy: A02

Microfiche copy: A01 
Distribution Category:

Safeguards - Nuc lear Materials Security

(UC-15)

ANL-82-49

$$
\begin{aligned}
& \text { ANL- }-62-49 \\
& \text { DE82 } 021235
\end{aligned}
$$

ARGONNE NATIONAL LABORATORY

9700 South Cass Avenue

Argonne, Illinois 60439

NDA SAREGUARDS TECHNIQUES FOR LMFBR ASSEMBLIES

by

P. J. Persiani and M. L. Gundy*

Applied Physics Division

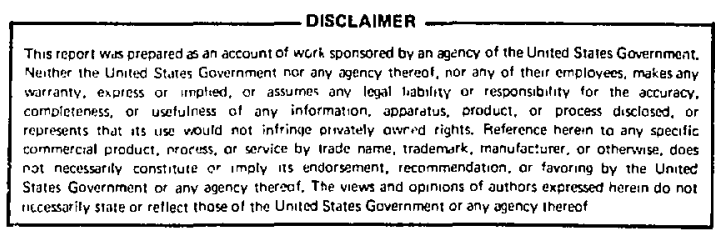

August 1982

*Participant in the Research Program, 1981, ANL Division for Educational Programs 
I. INTRODUCTION ............................ 1

II. REFERENCE LMFBRS AND FUEL HANDLING SYSTEMS . . . . . . . . . . 2

A. Item Flow In Fuel Handling System . . . . . . . . . . 3

B. Direct Accountability of Fissile Material . . . . . . . 4

c. Instruments and Methods for Determining Nuclear-Material Content . . . . . . . . . . . . . 4

1. HIgh Resolution Gama Spectrometry . . . . . . . . . 4

2. High-level Neutron CoIncidence Counter (HLNCC) ...... 4

3. Aative-wel1 Neutron-interrogation system (AWCC) . . . . 8

D. Diversion Analysis .................... . 8

III. SUMMARY REMARKS . . . . . . . . . . . . . . . . . 10

REFERENCES . . . . . . . . . . . . . . . . . . . . . . 11 


\section{LIST OF FIGURES}

Page

1. Curfum Isotope Concentrations vs. Burnup ............. 5

2. Neutron Yield v8. Burnup In Three Core Regions . . . . . . . . 5

3. Neutron Yield v8. Burnup in Blanket Region . . . . . . . . . 6

\section{LIST OF TABLES}

Page

I. Data for Reference LMFBR Fuel and Blanket Assemblies . . . . . . 3

II. Principal Sources of Neutrons In Irradiated $\mathrm{UO}_{2}$ Materlals . . . 6

III. Spontaneous Fission Neutron Yield Reference (35 kg HM) Core Assembly $\left(10^{6}\right.$ Neutron/s) .............. 7

IV. Isotopic Neutron Yields Experiments (PFR) and Computations (Ref. LMFBR) . . . . . . . . . . . . . . . 8

v. Diversion Analysis Neutron Interrogation Sensitivity . . . . . 9 
NDA SAFEGUARDS TECHNIQUES FOR LHFBR ASSERLIES

\author{
P. J. Persiani and M. L. Gundy \\ Applied Physics Division \\ Argonne National Laboratory \\ Argonne, Illinols 60439
}

\begin{abstract}
AB STRACT
The significant safeguards concerns for liquid-aetal fast breeder reactors (LMFBRs), and for the LMFBR fuel handling systems are the accountability, surveillance, and identification of fuel and blanket assemblies. The introduction of fuel assemblies with a high content of $\mathrm{Pu}$ into the recelving and shipping areas of the LMFBR fuel cycle does allow a more direct near-real-time assay profile of the disposition of Pu. Isotope correlations and neutron assay methods have been investigated and implemented for determining plutonium and burnup in fresh and spent LMFBR fuel assemblies. The methods are based on active and passive neutron colncidence counting (NCC) techniques. Preliminary studies on neutron yield rates from the spontaneous fission of plutonium and curlum isotopes have Indicated that the NCC system is a most effective measure in the verification of nuclear material flow in assembly form for the entire reactor fuel handling cycle 1 .e., from the fresh-to the spent-fuel stage. A consequence of the high plutonium concentration level throughout the fuel Irradiation period in an LMFBR, is that the spontaneous fission neutron yield from the 242-curium and 244-curium does not dominate the spontaneous fission neutron yield from the plutonium lsotopes in the spent fuel stage.
\end{abstract}

\title{
I. INTRODUCTION
}

This study describes selected nondestructive assay safeguards techniques which may be applicable for current and near-term fast breeder reactors (FBR).

Safeguards for nuclear fuel cycles should be considered in the context of a world deployment of various reactor types and a varying availability of fuel cycle services. This is particularly true of the current experimental, demonstration, and prototypal fast breeders, which must be fueled and sajeguarded in the transition period. The quantities of plutonium and uranium fissile materials, the fuel handing systems, and the storage methods for the fuel assemblies of fast breeders will have a significant impact on safeguards techniques. The plutonium and fissile uranium throughput, the high fissile content, and the use of sodium coolant for the 1iquid-metal fast breeder reactor (LMFBR) fuel cycles may require development of additional safeguards techniques beyond those for the thermal light-water reactor (LWR) fuel cycle:

The feasibility of, and the limitations and constraints on, the application of certain safeguards measures and techniques for the IMFBR are not in comon with LWR systems. Important distinctions of the LMFB fuel cycle are: 
the total quantity of nuclear material in inventory and in flow; the concentration levels of nuclear material in single items (assemblies); the assembly-handling operations and storage facllities; the reactor operating modes. The total quantity of nuclear material in inventory and in flow for each demonstration and commercial breeder reactor sygtem would be 3,000-10,000 $\mathrm{kg}$ of plutonium, which is in the range more of the: annual flow rates of 6,000-12,000 kg for current and proposed large LWR reprocessing plants. The content of the fissile material, 6-15 kg of plutonium, in each of the fresh and spent fuel assemblies is on the order of the IAEA significant-quantity guideline of $8 \mathrm{~kg}$.

A timely perspective for developing LMFBR safeguards is obtained by considering that the existing experimental reactors have plutonium flow rates and inventory quantities (ranging from $1 / 2$ to 2 tonnes of plutonium) which is comparable to some current size reprocessing and mixed oxide fabrication plants having flow rates of about 200 tonnes of heavy metal ( 1 to 2 tonnes of platonium) per year. Consequently, in the context of near-term nuclear power development, the deployment of LMFBRs and reprocessing facilities appear to be on a comparable time-scale with impact on safeguards system development needs closely coupled.

\section{REFERENCE LMFBRS AND FUEL HANDLING SYSTEMS}

The facility design features of the generic LMFBR reference reactors and fuel handling systems are primarily based on two general classes of reactors: (1) demonstration and commercial, and (2) experimental -- currently in operation, under construction, or in the design stage. ${ }^{I}$ The former class includes SNR-300 (Federal Republic of Germany, or FRG), Monju (Japan), Phenix and Super Phenix (France), BN-350 and BN-600 (USSR), and the CRBR (US). The scale of the experimental reactors falls into two categories: power ratings (1) higher than $100 \mathrm{MWt}$ and (2) lower than $100 \mathrm{MWt}$. In the first category are the FFTF (US) and the PFR (UK). In the second are EBR-II (US), the KNK-2 (FRG), Joyo (Japan), FBTR (India), and the BOR-60 (USSR).

The basic units of one fuel assembly and one blanket assembly have been adopted for item accountability with reactors in the normal operating mode. However, for the experimental reactors, experimental requirements and experimental-assembly designs necessitate the more restrictive item accountability by fuel element (pin). Generally, the fuel assemblies for the operating power reactors differ from those for the experimental reactors in dimensional design, dismantling capabilities, frequency and mode of handling, plutonium and 235-U content, and burnup rate and average burnup. These differences necessitate investigating variations in requirements for diversion path analysis, safeguards measures, item accountability, and containment and surveillance $(\mathrm{C} / \mathrm{S})$ techniques.

Since the safeguards system will have some components that are plantspecific even within each class and category of reactor, the safeguards anaiysis usually includes three general considerations: (1) verification of the inventcry of fresh fuel assemblies in handling and storage; (2) verification of the inventory of irradiated fuel asssemblies in storage and in preparation for transport; and (3) handling systems for irradiated fuel assemblies. In some plants, experimental assemblies or fuel assemblies nust be dismantled and given special handing and storage. The requirements for 
verifying Inventory and flow of these dismantled assemblies can be satisfled with item accountability adopted to the level of the Individual fuel elements within the assembly when necessary.

The differences between the core and blanket design detalls for the demonstration and commercial reactors and the experimental reactors have been categorized and are summarized in Table $I$.

TABLE I. Data for Reference LMFBR Puel and Blanket Assemblies

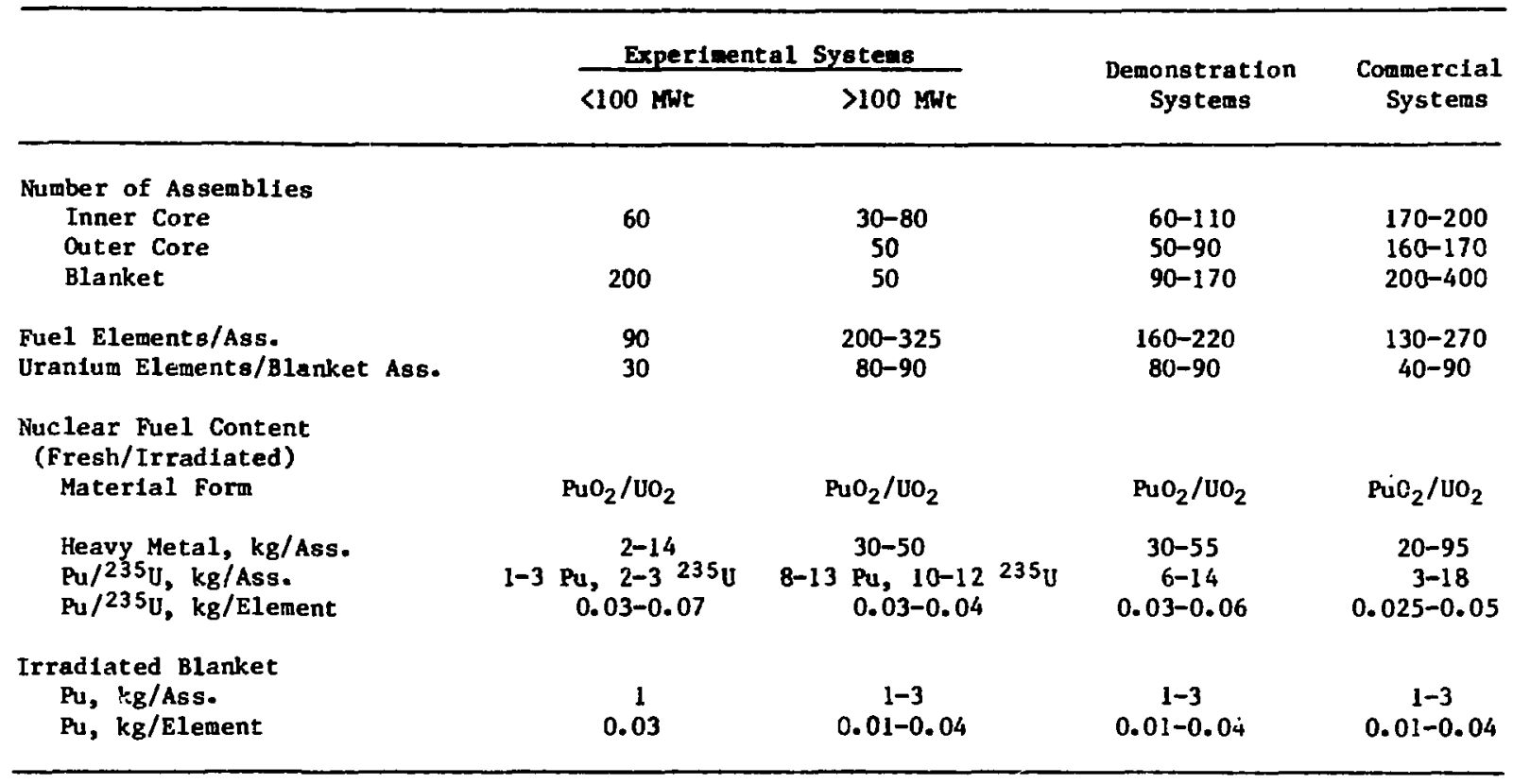

\section{A. Item Flow In Fuel Handling System}

The Item-accountability measure of fuel and blanket assemblies in the fuel-handling storage and operations, or in the reactor-operations facility, is formed by adding all measured recelpts to the intilal inventory and subtracting all measured removals from the final measured inventory. During the normal flow of uniquely identified assemblies, nuclear-materials control emphasizes administrative controls supplemented by secure storage for the Identifled assemblies, tamper-indicating assembly seals or systems of seals, sealed containers or transport casks for receiving and shipping, etc. Linited measurement capabilities and the uncertainties of the nuclear-material content in the assemblies, may obscure the diversion of significant quantities of nuclear materlals from a plant.

Item accountability and the accountability of the nuclear-material contained in the assembly become equivalent only when there is assurance that the Integrity of the assembly and 1 ts contents has been maintained. The use of neutron interrogation techniques for nondestructive assay (NDA) would provide direct assurance that the integrity of the nuclear-material content has not been compromised since the fabrication of the assembly. The introduction of fuel assemblies with a high content of $\mathrm{Pu} / 235 \mathrm{U}$ into the recelving and shipping areas of the fuel cycle does allow a nore direct near-real-time 
assay profile of the disposition of $\mathrm{Pu} /{ }^{235} \mathrm{U}$. Infornation on the tineiy disposition of assembly flow 18 obtained from the direct applicability of material accountancy by $\mathrm{NDA}$ methods (HLNCC) $2,3,4,5$ and from the selective application of effective C/S techniques.

The distinction must be maintained between NDA neutron-colncidence counting, ICC systems of measurements for nuclear-material accounting in the sense of nuclear material balance accountancy and NDA for the verification of nuclear-material content for accountability in an assembly. It is only in the latter sense that NDA is recomended in this report.

\section{B. Direct Accountability of Fissile Material}

Both the IAEA safeguards approach for the long-term handling and interim storage of fresh and spent fuel assemblies, and the international transfer of ownership of the fuel with resolutions of shipper/ receiver balances, require direct identification of fissile content and accountability of nuclear-material balance. The currently available NDA techniques for item accountability can distinguish only between different classes of assemblies, e.g., fuel, blanket, and dummy replacement. No distinction can be made between the individual assemblies of one class. It is not clear how effective NDA techniques may be if the NDA information is not supplemented by subsequent confirmatory information that a replacement or partial replacement has been made. An added level of assurance in flow verification and nuclearmaterial accountancy is provided by establishing that the difference between preirradiation and postirradiation isotopic measurements reflects the irradiation history of a specific assembly.

A number of instruments which have been assessed for application as NDA safeguards for item accountability include: high resolution gamma spectroscopy (HRGS) for passive gamma-ray spectrometry of plutonium; the high level neutrun-coincidence counter HLNCC for passive measurement of spontaneous fission neutrons from ${ }^{240} \mathrm{Pu}$, and the active-well neutron-coincidence counter AWCC interrogation system for measuring induced-fission neutrons in fissile isotopes.

c. Instruments and Methods for Determining Nuclear-Material Content

1. High-resolution Gamma Spectrometry (HRGS)

In view of the high plutonium content in LMFBR mixed-oxide fuel, the plutonium assay by HRGS appears to be more effective for fresh fuel elements than for complete fresh fuel assemblies. The self-shielding effects in fuel elements are expected to be minimal, and consequently the gamma-ray spectra may be used as a quantitative measure of the plutonium content. The self-attenuation of the gamma rays in an LMFBR assembly, with or without sodium, would introduce uncertainty in the quantitative measure of the plutonium-content in a fresh fuel assembly. The direct assay of plutonim in an Irradiated assembly by HGRS does not appear to be an effective measurement technique except to establish the existence of fission products.

\section{High-1evel Neutron Colncidence Counter (HLNCC)}

fission of the ${ }^{238} \mathrm{Pu},{ }^{240} \mathrm{Pu}$, and ${ }^{242} \mathrm{Pu}$ have indicated that the HLNCC 18 
effective in the verification of nuclear-material flow in assembly form throughout the entire reactor fuel handling cycle, 1.e., from the fresh-fuel through the spent-fuel stages. Because of the high plutonium concentration throughout the fuel-irradiation period in an LMFBR, the spontaneous-fission (SF) neutron yields from the ${ }^{242} \mathrm{Cm}$ and ${ }^{244} \mathrm{Cm}$ do not doninate the $S F$ neutron yield from the plutonium isotopes in the spent-fuel stage. This is significant when compared to the problem with LWR spent-fuel interrogation where the ${ }^{244} \mathrm{~cm}$ neutron yield rate is several orders of magnitude greater than the plutonium yield rate at the same level of burnup and after the decay of the short-1ife $(162.8 \mathrm{~d}){ }^{242} \mathrm{Cm}$ contribution. The relative curiun isotopic concentration buildup as a function of average burnup of LWR and LMFBR fuel assemblies are compared in Fig, 1 .

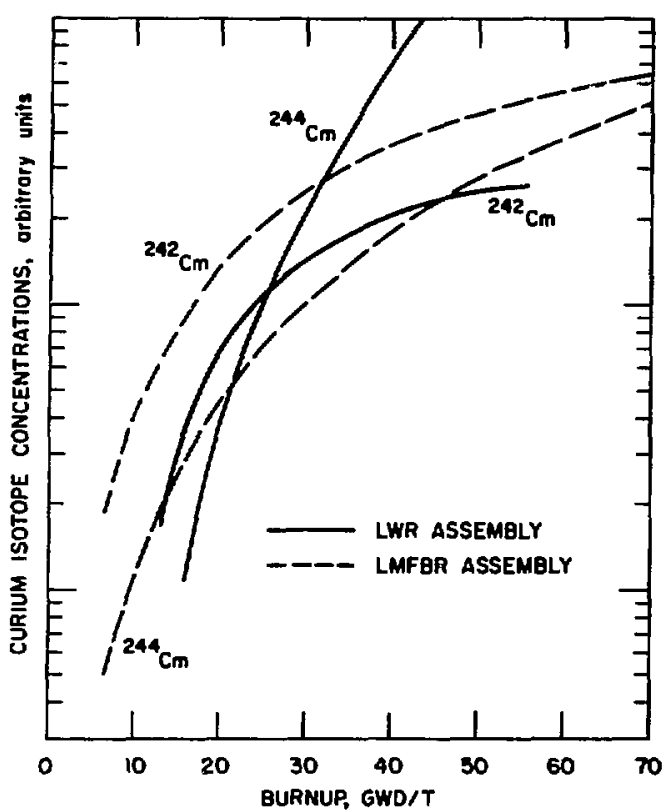

Fig. 1. Curium Isotope Concentrations vs. Burnup
In the LWR system, the long-1ife $244 \mathrm{Cm}$ isotope begins to dominate at burnup levels of about 20,000 to $25,000 \mathrm{MWd} / \mathrm{T}$. In the JMFBR systems the cross-over occurs at average burnup levels of greater than $100,000 \mathrm{MWd} / \mathrm{T}$.

Initial computations of total neutron yield rates [SF and $(\alpha, n)^{18} 0$ ] for the prominent isotopes are plotted as a function of fuel burnup in Figs. 2-3. The computations are results from a study of isotopic-safeguards techniques in LFFR fuel cycles. ${ }^{6}$ Figures $2 a, 2 b$, and $2 c$ represent different core regions where possible differences in enrichment and spectral effects were studied. In all regions, the results indicate that, for mixed-oxide fuel with a burnup of 35,000 MWd/T, about half the total neutron yleld rate is contributed by plutonium after a cooling period of 1-2 yr and subsequent decay of the ${ }^{242} \mathrm{Cm}$ isotope. From the specific isotopic neutron
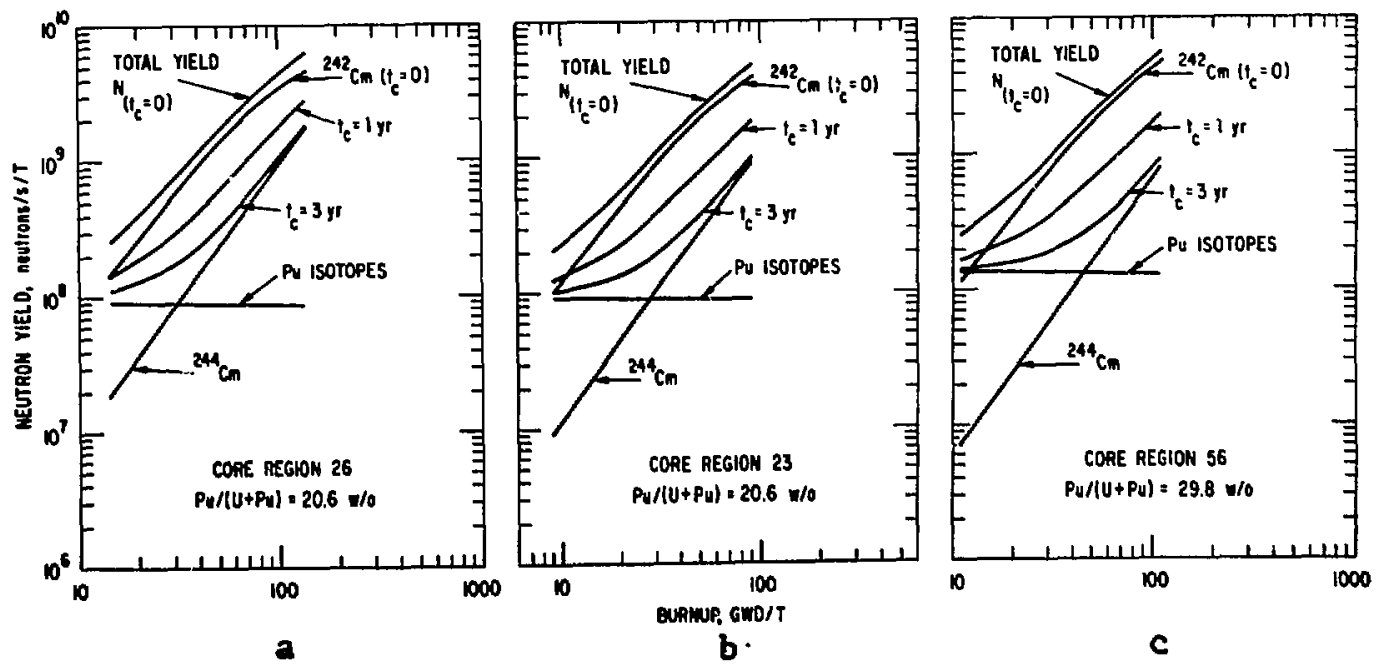

Fig. 2. Neutron Yield vs. Burnup in Three Core Regions 


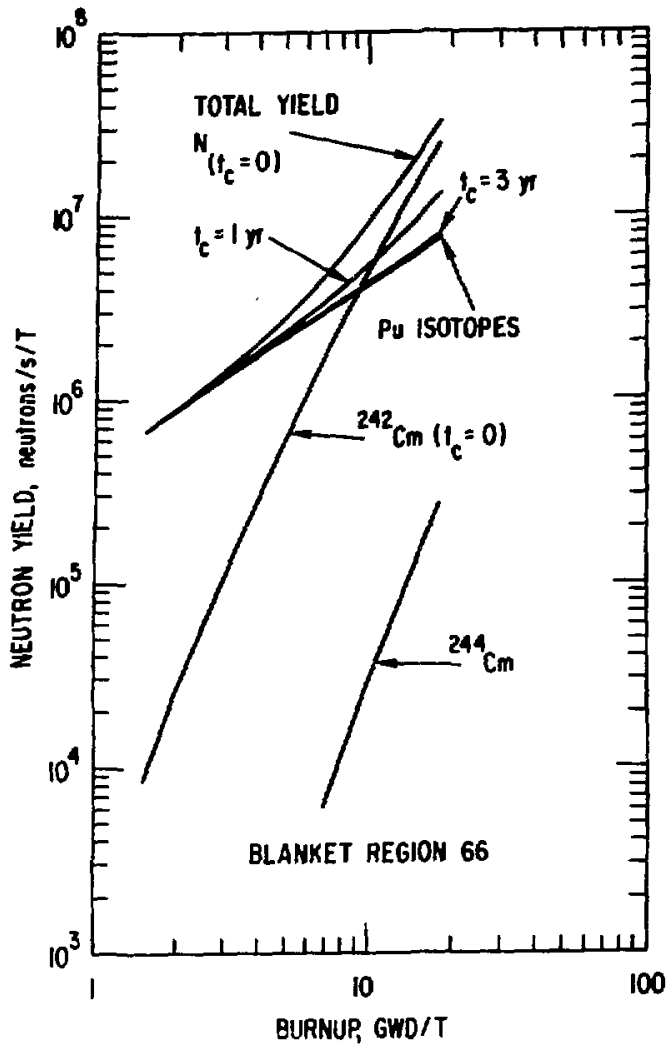

Fig. 3. Neutron Yield vs.

Burnup in Blanket Region ylelds, listed in Table II, it is estiwated that the plutonius SF neutrons entted primarily by the $240 \mathrm{Pu}$ (and some ${ }^{238} \mathrm{Pu}$ ), contribute about 25-35\% of the total SF neutrons emitted fron the fuel.

The plutonium isotopes will make a significant contribution to the $\mathrm{SF}$ neutron yields at all the levels of burnup and decay-cooling times that are anticlpated in the next two decades of LMFBR operation. This maintains even for a burnup of $100,000 \mathrm{MWd} / \mathrm{T}$, where the plutonium isotopes are estimated to contribute $5-77$ to the SF neutron yield, depending on decay cooling times. At burnups in the range of 75,000 $\mathrm{MWd} / \mathrm{T}$, the estimates indicate that the plutonium isotopes contribute 5-12\% of the total SF neutrons after a 2-yr cooling period. For the core region with the higher concentration level of plutonium (region 56, Fig. 2c), the fraction of the plutoniun SF neutrons is higher than in the core axial-center region 26 and the core axialedge region 23 of lower enrichment. At burnups below 33,000 MWd/T, the plutonium SF neutrons dominate the neutron yieid rate. These significant contributions to the neutron yield by the plutonium isotopes make passive-neutron-assay techniques a viable method for item accountability
and identification of the spent fuel and blanket assemblies in the LMFBR cycle.

TABLE II. Principal Sources of Neutrons in Irradiated $\mathrm{NO}_{2}$ Materials

\begin{tabular}{|c|c|c|c|c|c|c|}
\hline \multirow[b]{2}{*}{ Isotope } & \multirow[b]{2}{*}{$\operatorname{Ha} 1 \mathrm{f}-1 \mathrm{Ife}, \mathrm{yr}$} & \multicolumn{5}{|c|}{ Neutrons Produced per gram-second } \\
\hline & & $(\alpha, n)$ & Reaction & Spontaneous Fission ${ }^{a}$ & & Total \\
\hline $\begin{array}{l}235 U \\
238 U\end{array}$ & $\begin{aligned} 7.038 & \pm 0.005 \times 10^{8} \\
4.4683 & \pm 0.0024 \times 10^{9}\end{aligned}$ & $\begin{array}{l}7.21 \pm 0 \\
8.43 \pm 0\end{array}$ & $\begin{array}{l}0.72 \times 10^{-4} \\
0.84 \times 10^{-5}\end{array}$ & $\begin{array}{l}3.86 \pm 0.99 \times 10^{-4} \\
1.36 \pm 0.02 \times 10^{-2}\end{array}$ & $\begin{array}{l}1.11 \\
1.36\end{array}$ & $\begin{array}{l} \pm 0.12 \times 10^{-3} \\
\pm 0.02 \times 10^{-2}\end{array}$ \\
\hline $\begin{array}{l}238 \mathrm{Pu} \\
239 \mathrm{Pu} \\
240 \mathrm{Pu} \\
242 \mathrm{Pu}\end{array}$ & $\begin{aligned} 87.71 & \pm 0.03 \\
2.4131 & +0.0016 \times 10^{4} \\
6.570 & \pm 0.006 \times 10^{3} \\
3.763 & \pm 0.009 \times 10^{5}\end{aligned}$ & $\begin{array}{l}1.56 \pm \\
4.25 \pm \\
1.56 \pm \\
2.27 \pm\end{array}$ & $\begin{array}{l}0.16 \times 10^{4} \\
0.43 \times 10^{1} \\
0.16 \times 10^{2} \\
0.23\end{array}$ & $\begin{aligned} 2.60 & \pm 0.11 \times 10^{3} \\
8.85 & \pm 0.10 \times 10^{2} \\
1.743 & \pm 0.015 \times 10^{3}\end{aligned}$ & $\begin{array}{r}1.82 \\
4.25 \\
1.04 \\
1.743\end{array}$ & $\begin{array}{l} \pm 0.16 \times 10^{4} \\
\pm 0.43 \times 10^{1} \\
\pm 0.19 \times 10^{3} \\
\pm 0.015 \times 10^{3}\end{array}$ \\
\hline $241 \mathrm{Am}$ & $432.0 \pm 0.2$ & $3.17 \pm 0$ & $0.32 \times 10^{3}$ & & 3.17 & $\pm 0.32 \times 10^{3}$ \\
\hline $\begin{array}{l}242 \mathrm{Cm} \\
244 \mathrm{Cm}\end{array}$ & $\begin{array}{l}0.4456 \pm 0.0001 \\
18.099 \pm 0.015\end{array}$ & $\begin{array}{l}4.48 \pm 0 \\
8.82 \pm 0\end{array}$ & $\begin{array}{l}0.45 \times 10^{6} \\
0.88 \times 10^{4}\end{array}$ & $\begin{aligned} 2.25 & \pm 0.08 \times 10^{\prime} \\
1.081 & \pm 0.007 \times 10^{\prime}\end{aligned}$ & $\begin{array}{r}2.70 \\
1.090\end{array}$ & $\begin{array}{l} \pm 0.09 \times 10^{7} \\
\pm 0.007 \times 10^{7}\end{array}$ \\
\hline
\end{tabular}

aeference value for spontaneous values.

$\bar{v}_{\mathrm{sp}}=3.756$ for ${ }^{252} \mathrm{Cf}$. 
The unique characteristic of the LMFBR system that relates to the verification of nuclear-material flow in core assemblies is the almost constant plutonium concentration in reactors with core conversion ratios uf approximately 0.7 and greater. Although the relative concentrations of the plutonium isotopes may vary over extended periods of burnup, the SF neutron yields from the plutonium are almost constant over an irradiation period extending to about $100,000 \mathrm{MWd} / \mathrm{T}$. Table III gives the SF neutron yields for a reference core

TABLE III. Spontaneous F:Bsion Neutron Y1eld Reference ( $35 \mathrm{~kg} \mathrm{HM}$ ) Core Assembly $\left(10^{6}\right.$ Neutrons/s)

\begin{tabular}{ccccccc}
\hline Average Burnup & \multicolumn{4}{c}{ Plutonium } & \multicolumn{2}{c}{ Curium } \\
\hline (MWd/T) & 238 & 240 & 242 & Total & $\begin{array}{c}242^{a} \\
\left(t_{c}=0\right)\end{array}$ & 244 \\
0 & 0.18 & 1.2 & 0.30 & 1.68 & - & - \\
12,000 & 0.17 & 1.23 & 0.30 & 1.72 & 1.51 & 0.30 \\
35,000 & 0.16 & 1.29 & 0.33 & 1.78 & 12.38 & 2.69 \\
77,000 & 0.13 & 1.39 & 0.36 & 1.87 & 58.63 & 14.12 \\
96,000 & 0.12 & 1.42 & 0.36 & 1.91 & 70.74 & 22.90 \\
\hline
\end{tabular}

$a_{\text {Half-11fe }}=162.8$ days

between the fresh fuel and the spent fuel in a given curium concentration gives a direct measure of the irradiation history of the assembly. This difference-method of determining the curium concentration has the advantage of allowing use of the time decay of ${ }^{24} \mathrm{Cm}$ as a consistency check in the physical-inventory verification of the stored assemblies. The high concentration of ${ }^{242} \mathrm{Cm}$ at high burnups is unique to LMFBRs, and presents the opportunity for the inspector to make a timely in-the-field assessment as to a possible anomaly in the flow of nuclear material in the assembly handling operations of the reactor.

Figure 3 indicates that the plutonium should dominate the SF neutron yield rate over the burnup periods anticipated for the blanket assemblies in all classes of reactor systems.

Preliminary results of 1sotopic content experiments from the reprocessed fast breeder fuels of the UKAEA Dounraey Prototype Fast Breeder reactor $(P F R)^{7}$, indicate that for spent fuels at the burnup level of about $70,000 \mathrm{MWd} / \mathrm{T}$, and a decay cooling period of 180 days, the plutonium isotopes contributed $7 \%$ of the S.F. neutrons measured, with the remaining $93 \%$ being those of the curium isotopes. Additional total neutron emission measurements made at Dounraey on a single irradiated PFR pin, having a burnup history of $65,000 \mathrm{MWd} / \mathrm{T}$ and a cooling period of approximately 3 years, showed that $70 \%$ of the neutrons were emitted by the curfum isotopes, and the remaining $30 \%$ (including some contribution from $\alpha, n$ reactions) were emitted by the plutonium isotopes. These experimental results outlined in Table IV, corroborate the conputed estimates for the reference LMFBR and appaar to give a consistent correlation betweeis the 1sotopics and neutron emissions, including the time decay of neutron yields due to the time decay of the $242 \mathrm{Cm}$ isotope. 
The HLNCC measurements are of major safeguards importance in. verifying plutonium flow accountancy data well within the time period before the reprocessing operation. The KLNCC systems would have to be modified in order to minimize the interference of the high gamma-ray radiation background of the spent fuel. This may be done through selection of neutron detectors and/or Incerspersing a gamma-ray attenuation material such as lead between $t t_{i}=$ assemb1y and the detection system. The placement and operation of the HLNCC measurement system at key measurement points are plant-design-specific, and modifications in designs would be required to accommodate the specific plant features.
TABLE IV. Isotopic Neutron Yields Experimente (PFR) and Computatione (Ref. LYPBR)

Reprocessed PFR Assembly: 70,000 rwd/T (5th cycle), 180 days decay cooling period

Total Neutron Yields

\begin{tabular}{cc}
\hline Experiment (PFR) & Computed (Ref. LMFBR) \\
\hline $7 \% \mathrm{Pu}$ & $12 \pi \mathrm{Pu}$ \\
$93 \% \mathrm{Ca}$ & $887 \mathrm{Cr}$ \\
\hline
\end{tabular}

Reprocessed Single PPR Fuel Pin: 65,000 mw/T,

3 year decay cooling period

Total Neutron Yields

\begin{tabular}{ccc}
\hline Exper1ment (PFR) & \multicolumn{2}{c}{ Computed (Ref. LMFBR) } \\
\cline { 2 - 3 } & $(19 \% / 0$ Pu Fuel) & $(27$ w/o Pu Fuel) \\
\hline $36 \%$ Pu & $27 \%$ Pu & $40 \% \mathrm{Pu}$ \\
$70 \% \mathrm{Cu}$ & $73 \% \mathrm{Cu}$ & $60 \% \mathrm{Cu}$ \\
\hline
\end{tabular}

\section{Active-well Neutron-interrogation System (AWCC)}

An IAEA safeguards measurement of complementary importance to the HLNCC measurements is the direct determination of total fissile $\mathrm{Pu} /{ }^{235} \mathrm{U}$ concentrations in the fresh and spent fuel assembly. For verification of material flow and physical inventory, the induced fission neutron rate measuremerits can be obtained by using an external neutron source of sufficient strength to effect a neutron multiplication above the total neutron yield rate. Fissile content in the assemblies may be determined by the AWCC system. The $241 \mathrm{Am}-\mathrm{LI}$ source system may be modified for use on spent fuel assemblies and designed for use as a dual purpose HLNCC.

\section{Diversion Analysis}

A diversion analysis study involving the substitution of $10 \%$ (22 of 217 fuel rods) and 20\% ( 59 of 217 fuel rods) of the central rods in a fuel assembly with depleted uranium rods was performed to explore the sensitivity to detect the substitution by both the passive and active modes of the HLNCC methods. The computational nodel for the detector assumed cylindrical geometry of the HINCC with a polyethylene detector region within which are placed the detectors ( ${ }^{3} \mathrm{He}$ or fission chambers). The detector radius was maintair.ad throughout the serles of computations to avoid geometric effects on the flux at the detector. The model for the case of using the HLNCC In the active mode assumed the external neutron source to be cylindrical and uniformiy distributed with zero radial extent, and positloned between the fuel assembly and detector region. The results of the scoping neutron transport computations for the passive and the active mode (with an external neutron source strength of $1.23 \times 10^{7} \mathrm{n} / \mathrm{sec}$ ) on an LMFBR fuel assembly are presented in Table V. The fuel assembly composition was that of a spent fuel assembly having undergone an average $40,000 \mathrm{MWd} / \mathrm{t}$. 
TABLE v. Diversion Analyeis Neutron Interrogation Seneitivity

\begin{tabular}{|c|c|c|c|c|c|}
\hline \multicolumn{6}{|c|}{ PASSIVE MEUTRONS } \\
\hline $\begin{array}{l}7 \text { Fuel } \\
\text { Diveraton }\end{array}$ & $\begin{array}{l}\text { Tetal } \\
\text { Source } \\
\text { (n/sec) }\end{array}$ & $\begin{array}{l}\text { Induced } \\
\text { plaston } \\
\text { (n/sec) }\end{array}$ & $\mathbf{H}$ & $\begin{array}{l}\text { Total Flux at } \\
\text { the Detector } \\
\text { (n/sec-ce? }\end{array}$ & $\begin{array}{l}x \text { Reduction in } \\
\text { Detector Flux }\end{array}$ \\
\hline 0 & $8.237 \mathrm{E}+6$ & $1.277 \mathrm{E}+6$ & 1.155 & $5.066 \mathrm{E}+3$ & $\mathbf{0}$ \\
\hline 10.0 & $7.413 \mathrm{E}+6$ & $1.025 E+6$ & 1.138 & $4.520 E+3$ & 10.8 \\
\hline 26.2 & $6.084 E+6$ & $6.9595 E+5$ & 1.114 & $3.653 E+3$ & 27.7 \\
\hline
\end{tabular}

EXTERHAL NEUTRON SOURCE STRENGTH $\left(1.232 \times 10^{7} \mathrm{n} / \mathrm{sec}\right)$

\begin{tabular}{|c|c|c|c|c|c|}
\hline $\begin{array}{l}7 \text { Fuel } \\
\text { Diversion }\end{array}$ & $\begin{array}{l}\text { Totel } \\
\text { Source } \\
(\mathrm{n} / \mathrm{sec})\end{array}$ & $\begin{array}{l}\text { Induced } \\
\text { Fission } \\
\text { (n/sec) }\end{array}$ & $\mathbf{M}$ & $\begin{array}{l}\text { Total Flux at } \\
\text { the Detector } \\
\text { (n/sec-cme }\end{array}$ & $\begin{array}{l}\text { Z Reduction in } \\
\text { Detector Plux }\end{array}$ \\
\hline 0 & $2.055 \mathrm{E}+7$ & $3.590 \mathrm{E}+6$ & 1.175 & $1.250 \mathrm{E}+4$ & 0 \\
\hline 10.0 & $1.973 \mathrm{E}+7$ & $3.206 \mathrm{E}+6$ & 1.163 & $1.193 \mathrm{E}+4$ & 4.2 \\
\hline 26.2 & $1.840 \mathrm{E}+7$ & $2.650 E+6$ & 1.129 & $1.1148+4$ & $11 . \overline{3}$ \\
\hline
\end{tabular}

axternal source background has been subtracted.

In the case of the passive HLNCC mode, the percent change in the induced fission and the total flux entering the detector regions indicate that the multiplication decreases as more fuel is removed. This multiplication effect results in a higher percentage decrease in the induced fission reactions than the change in the fuel and internal source. The flux at the detector changes by a slightly higher percentage than the change in the internai source. The major fraction of this change in the induced fission source is due to the refluction in the fuel region. Since the internal source overwhelms the induced fission, the change in the flux at the detector is more representative of the change in the internal source. The flux levels predicted at the detector indicate that a $10 \%$ fuel substitution or less can be detected if the intial flux level is known.

The introduction of a $0.3 \mathrm{MeV}$ energy spectra external neutron source is to determine the fissile content. The low energy neutron source is selected to avoid the fast fission effect in $238 \mathrm{~J}$. The external total source strength of $1.23 \times 10^{7} \mathrm{n} / \mathrm{sec}$ insreases the induced fission component by a factor of 3 and increases the flux at the detector by a of 3 and increases the flux at the detector by a factor greater than 2. The percent reduction of the induced fission follows the percent change of the fuel substitution. However, the respective change in the neutron flux of only 4.2 and $11.5 \%$ are to be expected at the detector region. This results from several considerations: a) the induced fission in the substituted fuel region is from the depleted uranium fast fission, and the specific induced fission radial profile is somewhat flatter in the center than at the outer edges of the fuel region. It appears that fuel substitutions in the order of magnitude used in this study may be detected using the HLNCC in the active mode, although not as readily as in the passive mode. 


\section{SUMRARY REMARKS}

The need for IAEA safeguards systems to be applied to IMFBR is near-term (a decade or so). Present programs to develop devices and techniques for Improved safeguards do not address these near-term needs. The assessment for inspection requirements emphasizes those safeguards measures that are currently avallable or may be available for fleld implementation by the Agency within the next 3 to 5 years. At the present time, the neutron coincidence counting (NCC) system can provide some verification of the nuclear-material content in the fuel and blanket assembly, but further development will be necessary efore it can be applied as a material balance accountancy measurement. 
1. P. J. Persian1, "Diversion Analysis and Safeguards Measures for LIquid Metal Fast Breeder Reactors," Argonne National Laboratory Report, ANL-81-48, ISPO-160 (October 1981).

2. J. R. PhIllips, et al., "Application of Nondestructive Gamma-Ray and Neutron Techniques for the Safeguarding of Irradiated Fuel Materials," Los Alamos National Laboratory, LA-8212 (May 1980).

3. J. R. Phillips, et al., "Neutron Measurement Techniques for Nondestructive Analysis of Irradiated Fuel Assemblies," Los Alamos National Laboratory," LA-9002-MS; ISPO-156 (November 1981).

4. H. O. Menlove and M. S. Krick, "The High Level Neutron Coinctdence Counter (HLNCC): Users Manual," Los Alamos National Laboratory, LA-7779-M (June 1979). See also "Description and Operation Manual for the Active Wel1 Colncidence Counter, Los Alamos National Laboratory, LA-7823-M (May 1979).

5. H. 0. Menlove, "Passive/Active Coincidence Collar for Total Plutonium Measurement of MOX Fuel Assemblies," Los Alamos National Laboratory Report, LA-9288-MS (ISP0-170), (May 1982).

6. P. J. Persiani, J. A. Goleb and T. K. Kroc, "Nuclear Material Safeguards Jurveillance and Accountancy by Isotope Correlation Techniques," Argonne National Laboratory Report, ANL-81-80, (November 1981), and Journal of Institute Nuclear Materials Management, Winter Issue, 1981, Vol. X, No. 4, p. 42 .

7. V. M. Sinclair, UKAEA, Dounraey Nuclear Power Development Establishment, Dounraey, Thurso, Scotland, Private Communication, 1981. 